\title{
Analisis Rasio Solvabilitas Untuk Mengukur Kinerja Keuangan Pada Bank SulutGo
}

\author{
Aditya Runtuwene \\ Frendy A.O. Pelleng \\ Wilfried S. Manoppo \\ Jurusan Ilmu Administrasi, Program Studi Administrasi Bisnis \\ Fakultas Ilmu Sosial dan Politik Universitas Sam Ratulangi \\ E-mail: adityaar1997@gmail.com
}

\begin{abstract}
This study aims to determine the financial performance based on Bank Sulut Go's solvency ratio. In this study quantitative descriptive research was used. Data collection techniques using documentation techniques, namely data obtained from documents in the form of financial statements of North Sulawesi Bank in 2014-2018. The analysis technique used is bank solvency ratio analysis consisting of Capital Ratio, Primary Ratio, Risk Assets Ratio, Secondary Risk Ratio, and Capital Adequacy Ratio. Based on the results obtained that the primary ratio, risk assets ratio, capital ratio, and capital adequacy ratio that pay attention to fixed assets, as well as PT Bank SulutGo capital adequacy ratio in 2014 - 2018 shows a trend of increasing. The minimum level of capital provision for Bank SulutGo is fulfilled from 2014 to 2018 in accordance with regulations concerning changes to Bank Indonesia Regulation Number: 7/15 / PBI / 2005 concerning the number of core capital of commercial banks which requires CAR to be at least $8 \%$.
\end{abstract}

Keywords: Financial Performance, Solvability Ratio

\section{Pendahuluan}

Laporan keuangan merupakan hasil dari proses akuntansi yang dapat digunakan sebagai alat untuk berkomunikasi antara data keuangan atau aktivitas suatu perusahaan dengan pihak-pihak yang berkepentingan dengan data atau aktivitas perusahaan tersebut. Laporan keuangan dapat di analisis dengan tujuan agar data lebih di mengerti sehingga menghasilkan informasi. Informasi tersebut diharapkan dapat bermanfaat bagi sebagian besar kalangan pengguna laporan keuangan dalam rangka membuat keputusankeputusan. Umumnya Laporan keuangan di gunakan secara luas, baik oleh pihak intern maupun oleh pihak eksternal perusahaan. Pihak intern adalah pihak yang membutuhkan informasi dari hasil analisis laporan keuangan untuk membantu mereka dalam mengelola, merencanakan, dan mengendalikan kegiatan perusahaan. Pihak 
intern perusahaan terdiri dari manajemen perusahaan, para membuat keputusan di perusahaan dan staf perusahaan. Analisis rasio keuangan, membantu mengetahui tingkat kinerja keuangan perusahaan apakah baik atau sebaliknya. Salah satu rasio keuangan yang digunakan untuk menilai kinerja keuangan perusahaan adalah rasio solvabilitas yang mengukur kemampuan perusahaan untuk melunasi seluruh utang yang ada dengan menggunakan seluruh aset yang dimilikinya. Dengan kata lain, rasio solvabilitas yaitu rasio yang digunakan untuk mengukur seberapa jauh aktiva perusahaan dibelanjai oleh utang.

Rasio solvabilitas bank berfungsi untuk mengetahui seberapa besar kecukupan modal bank untuk mendukung aktivitasnya. Penggunaan rasio solvabilitas dapat dilakukan dengan menggunakan berbagai komponen yang ada di laporan keuangan terutama laporan keuangan neraca, pengukurannya dapat dilakukan untuk berbagai periode operasi. Tujuannya agar terlihat perkembangan perusahaan dalam rentang waktu tertentu baik penurunan atau kenaikan, sekaligus mencari penyebab perubahan tersebut. Perusahaan dengan rasio solvabilitas yang tinggi (memiliki utang yang besar) dapat berdampak pada timbulnya risiko keuangan yang besar, tetapi juga memiliki peluang besar menghasilkan laba yang tinggi begitupun sebaliknya. Berdasarkan latar belakang tersebut, penulis merasa tertarik untuk melakukan penelitian dengan judul "Analisis Rasio Solvabilitas Untuk Mengukur Kinerja Keuangan Pada Bank Sulutgo",

\section{Laporan Keuangan}

Menurut Kasmir (2016) Laporan keuangan adalah laporan yang menunjukkan kondisi keuangan perusahaan pada saat ini atau dalam suatu periode tertentu. Sedangkan Menurut Fahmi dalam Sihombing (2011) laporan keuangan merupakan suatu informasi yang menggambarkan kondisi keuangan suatu perusahaan, dan lebih jauh informasi tersebut dapat dijadikan sebagai gambaran kinerja keuangan perusahaan.

Menurut Hery (2015) urutan laporan keuangan berdasarkan proses penyajiannya adalah sebagai berikut :

1. Laporan laba/rugi : Merupakan laporan yang sistematis tentang pendapatan dan beban perusahaan untuk satu periode.

2. Laporan Ekuitas pemilik : merupakan Sebuah laporan yang menyajikan ikhtisar perubahan dalam ekuitas pemilik suatu perusahan untuk satu pperiode waktu tertentu.laporan ini sering disebut sebagai laporan perubahan modal. 
3. Neraca : merupakan Sebuah laporan yang sistematis tentang posisi asset, kewajiban dan ekuisitas perusahaan pertanggal tertentu.

4. Laporan arus kas : merupakan sebuah laporan yang menggambarkan arus kas masuk dan arus kas keluar secara rerperinci dan masing masing aktifitas.

\section{Kinerja Laporan Keuangan}

Menurut Fahmi (2011) Kinerja keuangan adalah suatu analisis yang dilakukan untuk mellhat sejauh mana suatu perusahaan telah melaksanakan dengan meggunakan aturan-aturan pelaksanaan keuangan secara baik dan benar. Seperti dengan membuat suatu laporan yang telah memenuhi standar dan ketentuan dalam Standar Akuntansi Keuangan (SAK) dan lainya.

Menurut Van Horne (2014) Kinerja keuangan perusahaan merupakan salah satu faktor yang dilihat oleh calon investor sebelum menanamkan modalnya. Laporan keuangan yang diterbitkan perusahaan merupakan cerminan dari kinerja keuangan perusahaan. Informasi keuangan tersebut mempunyai fungsi sebagai sarana informasi, alat pertanggung jawaban manajemen kepada stakeholders, penggambaran terhadap indikator keberhasilan perusahaan dan sebagai bahan pertimbangan

dalam

pengambilan

keputusan.

\section{Analisis Rasio Keuangan}

Menurut Munawir (2010), analisis rasio keuangan adalah berorientasi dengan masa depan, artinya bahwa dengan analisa ratio keuangan bisa digunakan sebagai alat untuk meramalkan keadaan keuangan serta hasil usaha dimasa mendatang. Adapun Jenis-jenis rasio keuangan Menurut Kasmir (2013) yang digunakan dalam menganalisis perubahan tingkat rasio keuangan yaitu sebagai berikut :

1. Rasio Likuiditas merupakan rasio yang menggambarkan kemampuan perusahaan memenuhi kewajiban (hutang) jangka pendek".

2. Rasio profitabilitas merupakan Kemampuan perusahaan memperoleh laba dalam hubungannya dengan penjualan, total aktiva maupun modal sendiri.

3. Rasio aktivitas merupakan efektivitas perusahan dalam menggunakan aktiva yang dimiliknya atau dapat pula dikatakan rasio ini digunakan untuk mengukur tingkat efisiensi pemanfaatan sumber daya perusahan.

4. Rasio solvabilitas merupakan merupakan rasio yang digunakan untuk mengukur sejauh mana aktiva perusahaan dibiayai dengan utang. 


\section{Metode Penelitian}

Jenis penelitian ini merupakan penelitian deskriptif kuantitatif yakni analisis yang melaporkan hasil penelitian sesuai dengan fakta yang ada berdasarkan Laporan Keuangan Bank Sulutgo, dan juga penelitian ini digunakan untuk menilai kinerja keuangan Bank SulutGo dengan hanya menggunkan rasio solvabilitas. ruang lingkup penelitian yaitu mengenai Analisis Rasio Solvabilitas dan pada Bank Sulutgo tahun 2014-2018. Adapun teknik analisis data yang dipergunakan dalam penelitian ini adalah analisis rasio solvabilitas bank menurut kasmir (2013) yang meliputi :

1. Capital Ratio : merupakan rasio yang digunakan untuk mengukur permodalan dan cadangan penghapusan dalam menanggung perkreditan, terutama risiko terjadi karena bunga gagal ditagih.

2. Primary Ratio : Merupakan rasio yang digunakan untuk mengukur apakah permodalan yang dimiliki sudah memadai atau sejauh mana penurunan yang terjadi dalam total aset masuk dapat ditutupi oleh primary ratio.

3. Risk assets ratio digunakan untuk mengukur kemungkinan penurunan risk asset.

4. Secondary Risk Ratio Secondary risk ratio digunakan untuk mengukur penurunan aset yang mempunyai risk lebih tinggi.
5. Capital Adequacy Ratio digunakan untuk mengatasi resiko kerugian

\section{Hasil Penelitian}

Berdasarkan hasil penelitian analisis solvabilitas bank pada PT. Bank Sulutgo pada laporan keuangan periode 2014 2018 menunjukan hasil analisis sebagai berikut :

1. Capital Ratio

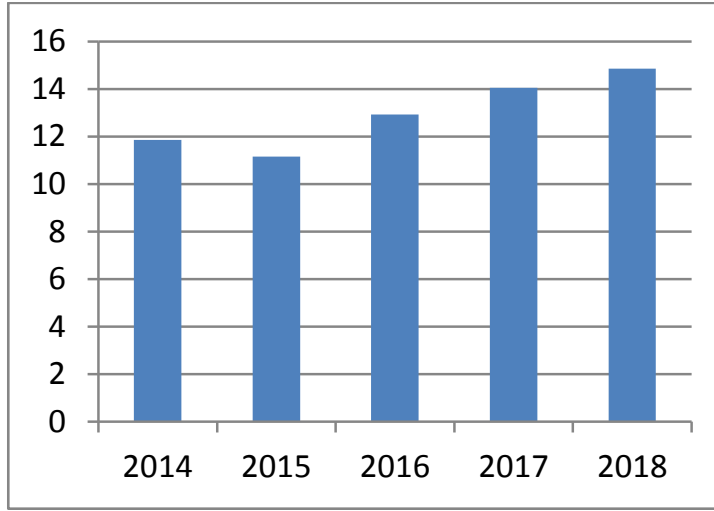

Pada tahun 2014 menunjuk pada angka $11,85 \%$, merupakan hasil bagi antara modal dan cadangan untuk kerugian aktiva produktif dengan total utang atau kewajiban Rp.7.399.978(juta). Pada tahun 2015, capital ratio terlihat menunjukkan angka $11,15 \%$, dibandingkan pada tahun sebelumnya $11,85 \%$. Modal mengalami kenaikan Rp.949.201(juta) dan cadangan atas kerugian aktiva produktif Rp.12.107(juta) yang mengalami penurunan, juga total utang Rp.8.618.027(juta) yang meningkat dibandingkan tahun sebelumnya berdampak sedikit penurunan capital ratio tahun 2015. Pada tahun 2016 capital ratio 
menunjuk pada angka $12,93 \%$, yang merupakan suatu peningkatan dari tahun sebelumnya yang hanya menunjuk pada angka $11.15 \%$. Jumlah modal Rp.1.258.004(juta), cadangan kerugian atas aktiva produktif Rp.8.454(juta), dan total kewajiban Rp.10.021.610(juta) yang mengalami peningkatan berpengaruh atas hal tersebut. Untuk tahun 2017 peningkatan angka capital ratio $(14,04 \%)$ kembali terjadi seiring dengan kenaikan dari tiga komponen yang menjadi dasar perhitungan capital ratio, baik modal Rp.1.445.942 (juta), cadangan kerugian atas aktiva produktif Rp.69.148 (juta), dan total kewajiban Rp.10.792.402 (juta). Dari dua kali peningkatan berturut-turut pada tahuntahun sebelumnya, pada tahun 2018 justru angka capital ratio sedikit menurun menjadi $14,85 \%$, tak lepas dari naiknya jumlah modal perusahaan menjadi Rp.1.617.696 (juta), serta naiknya jumlah total kewajiban menjadi Rp.10.968.976 (juta) dan cadangan atas kerugian aktiva produktif menjadi Rp.11.092 (juta).

3. Primary Ratio

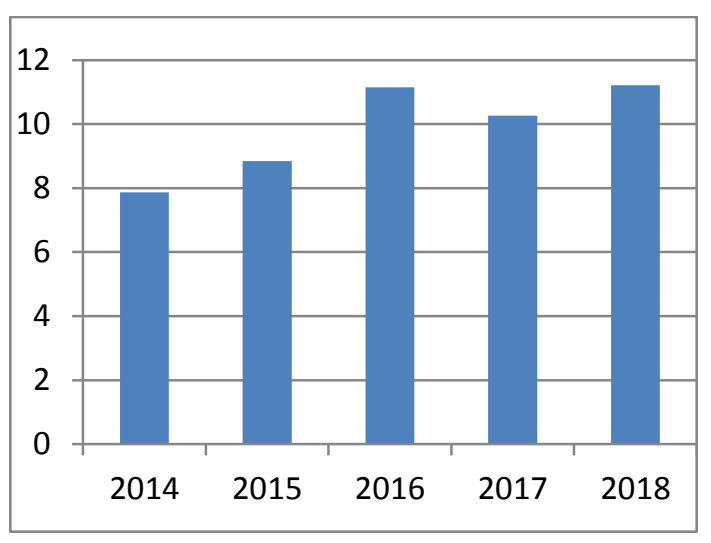

Berdasarkan hasil analisa diperoleh angka primary ratio yang di tunjukan pada tahun 2014 adalah 7,87\%, merupakan hasil bagi dari Rp.844.550(juta) dengan Rp.10.726.425(juta). Pada tahun 2015, angka primary ratio menunjukan pada angka $8,84 \%$, dimana terjadi kenaikan dari tahun sebelumnya. primary ratio pada tahun 2016 menujukan angka 11.15\%, dimana merupakan peningkatan dari tahun 2015 (8,84\%). Modal Rp.1.258.004(juta) dan aktiva perusahaan Rp.11.279.613(juta) yang menunjukan peningkatan dari tahun sebelumnya memberi dampak bagi peningkatan angka primary ratio di tahun 2016. Pada tahun 2017 membuat tingkat primary ratio di tahun 2017 menjadi $10,27 \%$. Adapun pada tahun 2018, primary ratio naik hingga pada angka $11,21 \%$, dari tahun sebelumnya yang menunjuk pada angka $10,27 \%$. 
2. Risk Assets Ratio

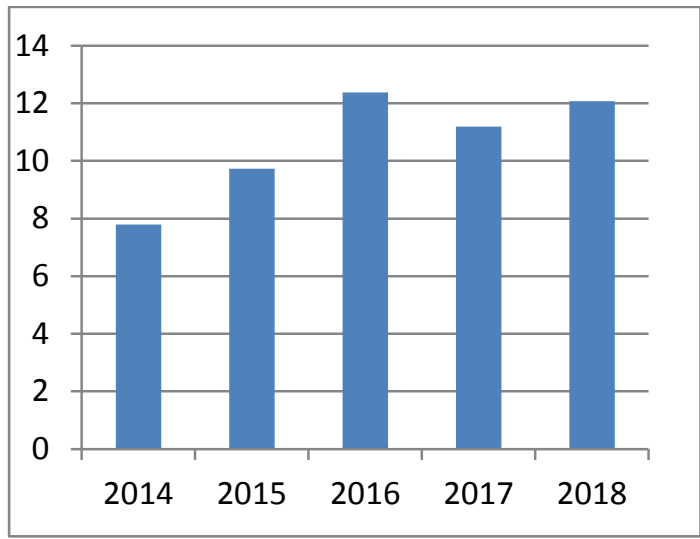

Pada tahun 2014 Risk assets ratio 7,49\% adalah Rp.844.550(juta), Pada tahun 2015 naik dari tahun sebelumnya menjadi $9,73 \%$. Modal yang bertambah yakni Rp.949.201(juta), pada tahun 2016 memperlihatkan peningkatan dari tahun sebelumnya yang menunjuk pada angka 9,73\%, pada tahun 2016 menjadi 12,38\%. Hal ini tentu dipengaruhi oleh naiknya jumlah modal pada jumlah Rp.1.258.004(juta) dan aktiva perusahaan pada jumlah Rp.11.279.613(juta). Serta kas Rp.311.544(juta) dan surat-surat berharga Rp.807.968(juta). Pada tahun 2017, risk assets ratio turun menjadi $11,19 \%$ dari tahun sebelumnya 12,38\%. Modal Rp.1.445.942 dan aktiva Rp.14.075.392 yang mengalami peningkatan, dan kas turun menjadi Rp.290.780 (juta) dan suratsurat berharga Rp.862.525 (juta) yang menyebabkan terjadinya penurunan angka risk assets ratio pada tahun 2017. Modal yang mengalami kenaikan dari Rp.1.445.942 (juta) menjadi
Rp.1.617.696(juta) pada tahun 2018, peningkatan total aktiva menjadi Rp.14.429.287(juta), dank kas Rp.311.673 (juta) walaupun dibarengi dengan penurunan surat-surat berharga yakni Rp.716.225(juta) membuat angka risk assets ratio naik dari tahun sebelumnya $11,19 \%$ menjadi $12,07 \%$

\section{Capital Adequacy Ratio}

Pada tahun 2014 capital adequacy ratio yang memperhitungkan aktiva tetap adalah 9,39\%. Angka ini merupakan hasil bagi antara modal Rp.844.550(juta) yang dikurang dengan aktiva tetap Rp.62.645(juta) dengan total kewajiban Rp.7.399.978(juta) yang dijumlahkan bersama surat-surat berharga Rp.928.056(juta). Sedikit kenaikan terjadi pada tahun 2015 , dimana dari $9,39 \%$ pada tahun 2014, CAR tahun 2015 naik pada angka 9,40\%. Modal yang bertambah menjadi Rp.949.201(juta), kenaikan aktiva tetap pada jumlah Rp.67.425(juta), penurunan jumlah surat-surat berharga pada jumlah Rp.761.001(juta), dan bertambahnya total kewajiban menjadi Rp.8.618.027(juta) membuat hasil perhitungan CAR 9,40\%. 


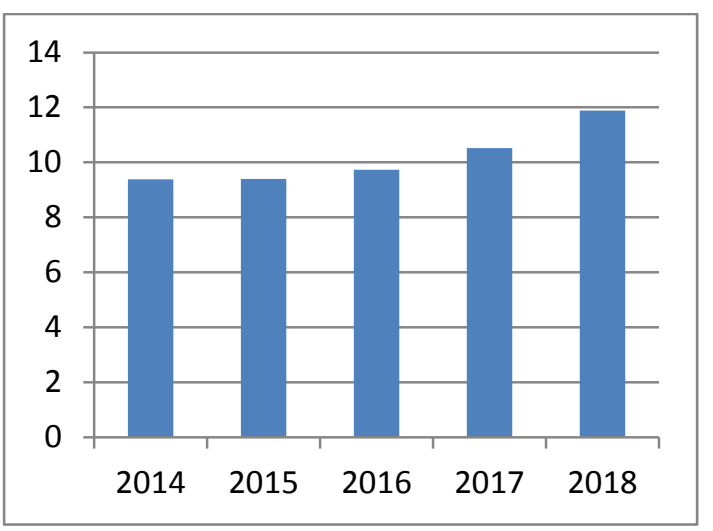

CAR tahun 2017 sebesar 10,52\%.

Naik dari tahun sebelumnya 9,73\% karena hasil peningkatan jumlah modal Rp.1.445.942(juta), total kewajiban Rp.10.792.402(juta), dan surat-surat berharga Rp.862.525(juta), serta penurunan aktiva tetap Rp.219.758(juta). Untuk tahun 2018, angka 11,88\% merupakan kenaikan CAR dari angka 10,52\% pada tahun 2017. Hal ini tidak lepas dari naik jumlah modal menjadi Rp.1.617.969(juta), aktiva tetap menjadi Rp.228.948(juta), dan surat-surat berharga menurun Rp.716.226(juta), serta total kewajiban yang meningkat menjadi Rp.10.968.976(juta).

\section{Capital Adequacy Ratio 3 (CAR 3)}

CAR tahun 2014 menunjukan angka $10,14 \%$ merupakan hasil bagi antara total kewajiban dan surat-surat berharga Rp.10.809.931(juta) dengan modal perusahaan Rp.844.550(juta). Kenaikan modal menjadi Rp.949.201(juta) dan suratsurat berharga menjadi Rp.761.001(juta), serta total menjadi Rp.8.618.027(juta) menyebabkan kenaikan $C A R$ pada tahun
2015 menjadi $11,80 \%$ dari tahun sebelumnya $10.14 \%$. Adapun dengan bertambahnya modal perusahaan pada jumlah Rp.1.258.004(juta) dan total kewajiban menjadi Rp.8.797.979(juta), serta bertambahnya surat-surat berharga pada jumlah Rp.807.968(juta) tahun 2016 membuat hasil perhitungan $C A R$ pada tahun tersebut meningkat dari tahun sebelumnya $10,12 \%$ menjadi $11,87 \%$. Pada tahun 2017 tingkat CAR kembali mengalami peningkatan setelah modal Rp.1.445.942(juta), total kewajiban Rp.10.792.402(juta), dan surat-surat berharga Rp.862.525(juta) mengalami peningkatan. CAR pada tahun 2017 pun menunjukan angka $12,41 \%$. CAR tahun 2018 menunjukan angka 13,84\%, mengalami kenaikan dibandingkan tahuntahun sebelumnya yang berkisar pada $12,41 \%$. kenaikan modal pada jumlah Rp.1.617.696(juta) dan surat-surat berharga pada jumlah Rp.716.226(juta), serta meningkatnya total kewajiban menjadi Rp.10.968.976(juta) memberi dampak atas hal tersebut. 


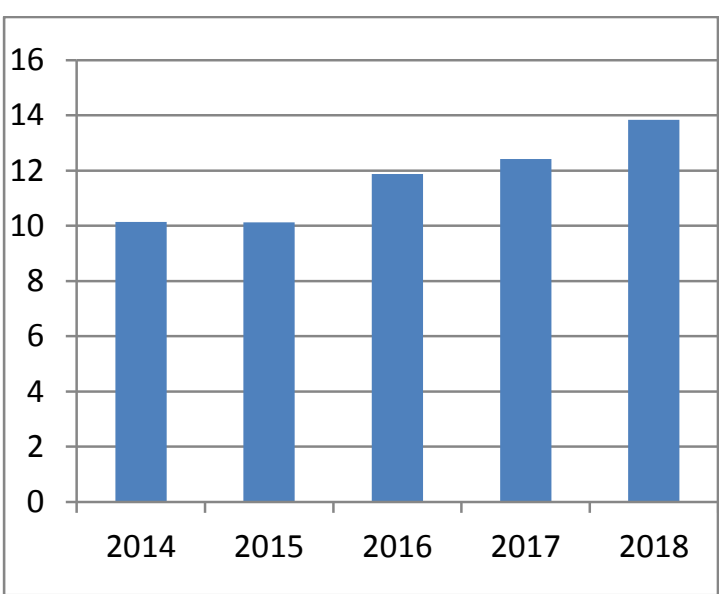

\section{Pembahasan}

Berdasarkan hasil analisis solvabilitas

PT. Bank Sulutgo tahun 2014 - 2018 adalah sebagai berikut:

Hasil penelitian ini menggunakan Capital ratio yang merupakan rasio yang digunakan untuk mengukur permodalan dan cadangan penghapusan dalam menanggung perkreditan, terutama risiko yang terjadi karena bunga gagal ditagih. Hasil analisis yang dilakukan menunjukan tren yang sama dengan dua rasio lainnya yakni primary ratio dan risk assets ratio, dimana pada tahun 2014 mengalami kenaikan dan pada tahun 2015 mengalami penurunan hal ini terwujud dari berkurangnya modal dan meningkatnya total kewajiban yang ditanggung perusahaan. Tahun 2016 cenderung naik begitu juga pada tahun 2017. Hal ini didukung dengan tumbuhnya modal dan total kewajiban perusahaan, serta cadangan atas kerugian aktiva produktif. Pada tahun 2018 terjadi kenaikkan yang disebabkan oleh bertambahnya modal, dan meningkatnya kewajiban perusahaan yang diimbangi pula dengan peningkatan jumlah cadangan untuk mengatasi kerugian atas kerugian aktiva produktif.

Hasil penelitian ini menggunakan Primary Ratio yang merupakan rasio yang digunakan untuk mengukur apakah permodalan yang dimiliki sudah memadai atau sejauh mana penurunan yang terjadi dalam total asset masuk dapat ditutupi oleh capital equity. Dari analisis rasio ini pada tahun 2014 menunjukan mengalami kenaikan sampai pada tahun 2015 sampai 2016 kemudian tahun 2017 turun dan pada tahun 2018 naik lagi. Tingkat primary ratio tahun 2017 turun, namun pada tahun naik. Dapat di lihat bahwa hal ini disebabkan oleh berkurangnya modal perusahaan yang diinvestasikan pada asset perusahaan yang mengalami peningkatan pada tahun 2018 .

Hasil penelitian ini menggunakan Risk Assets Ratio yang merupakan rasio yang digunakan untuk mengukur kemungkinan penurunan risk assets. Dari analisis yang dilakukan mulai tahun 2014 sampai tahun 2018 jelas terlihat mengalami kenaikan setiap tahunnya tidak sama seperti tingkat primary ratio yang mengalami penurunan di tahun 2015, risk assets ratio kembali cenderung naik pada dua tahun selanjutnya. Pertumbuhan modal dibarengi dan bertambahnya total aktiva terjadi pada tahun 2017, namun harus mengalami 
penurunan modal di tahun 2018 karena bertambahnya pula total aktiva.

Hasil penelitian ini menggunakan Capital Adequacy Ratio atau rasio kewajiban penyediaan modal minimum. Untuk mencari rasio $C A R$ perlu terlebih dahulu diketahui besarnya estimasi resiko yang terjadi dalam pemberian kredit dan risiko yang akan terjadi dalam perdagangan surat-surat berharga. Dari hasil analisis Capital Adequacy Ratio 2 (CAR2) yang memperhitungkan aktiva tetap tahun 2014 sampai 2018 menunjukan pula tren yang sama seperti hasil analisis tiga rasio di atas. Tahun 2014 sampai 2018 mengalami kenaikan pertahunnya. Kenaikkankenaikkan tersebut dipengaruhi oleh naiknya modal perusahaan, aktiva tetap, dan surat-surat berharga perusahaan, sedangkan total kewajiban meningkat

Hasil penelitian ini meng unakan Capital Adequacy Ratio 3 (CAR 3) menunjukan hasil analisis tahun 2014 mengalami kenaikan tetapi tahun 2015 mengalami penurunan dan pada tahun 2016 meningkat kembali sampai tahun 2018. Adapun peraturan Bank Indonesia No 9/12/PBI/2007 tentang perubahan atas peraturan Bank Indonesia No 7/15/PBI/2005 tentang jumlah modal inti minimum bank umum mengharuskan $C A R$ minimal 8 persen. Berdasarkan analisis CAR pada PT Bank Sulutgo tahun 2014 hingga 2018 menunjukan bahwa PT Bank Sulutgo telah memenuhi peraturan Bank Indonesia tersebut.

\section{Kesimpulan}

Kesimpulan dari analisis data dan pembahasan terhadap analisis Solvabilitas PT Bank Sulutgo adalah sebagai berikut : Bahwa tingkat primary ratio, risk assets ratio, capital ratio, dan capital adequacy ratio yang memperhatikan aktiva tetap, serta capital adequacy ratio PT Bank Sulutgo tahun 2014 - 2018 menunjukan tren terjadinya peningkatan. Jumlah modal, total aktiva dan total kewajiban yang berfluktuasi memberi dampak bagi tren atas Laporan Keuangan, khususnya Neraca dan Laporan Laba Rugi Bank SulutGo pada tahun 2014-2018. Tingkat penyediaan modal minimum bagi Bank umum seperti Bank SulutGo yang diatur dalam Peraturan Bank Indonesia Nomor ; 9/12/PBI/2007 tentang perubahan atas Peraturan Bank Indonesia Nomor : 7/15/PBI/2005 tentang jumlah modal inti bank umum dimana mengharuskan CAR minimal 8 persen dipenuhi dari tahun 2014 sampai tahun 2018.

\section{Saran}

Perusahaan harus meningkatkan kinerja keuangan dalam hal ini kemampuan perusahaan untuk menyediakan berupa 
modal dan pinjaman dalam kombinasi dana baik yang diatur sesuai kebutuhan dan kemampuan perusahaan sehingga dapat menghasilkan peningkatan yang terusmenerus atau berkelanjutan di setiap tahunnya. Dalam menghadapi situasi ekonomi yang tidak dapat diprediksi dengan sempurna, maka bank harus melakukan peningkatan terhadap penyediaan modal minimum bank dalam menghadapi situasi ekonomi yang mengharuskan perusahaan untuk tetap berada pada standar yang telah ditetapkan untuk menjamin kepercayaan yang diberikan oleh nasabah dan stakeholders lainnya, serta mempertahankan fungsinya sebagai financial intermediary, atau secara lebih spesifik bank yang berfungsi sebagai agent of trust (lembaga yang landasannya adalah kepercayaan), agent of development (lembaga yang memobilisasi dana untuk pembangunan ekonomi), dan agent of services (lembaga yang memberikan penawaran jasa perbankan yang lain kepada masyarakat).

\section{Daftar Putsaka}

Fahmi I. 2011. Analisis Laporan Keuangan. Alfabeta: Bandung. Skripsi Asri Amelia Sihombing, Juni 2016

Hery, 2015. Analisis Keuangan. Yogyakarta : CAPS
Horne, James C.Van dan J.M. Wachowicz Jr, 2014. Prinsip - Prinsip Manajemen Keuangan (Fundamentals of Financial Management. Jakarta : Salemba Empat. Jurnal Manajemen Vol. 15 NO. 1, MEI 2018.

Kasmir, 2013. Analisis Laporan Keuangan. Cetakan Keenam. Jakarta: Raja Grafindo Persada 2016. Analisis Laporan Keuangan. Jakarta : Rajawali Pers.

Munawir, 2010. Analisis Laporan Keuangan. Liberty : Yogyakarta. Jurnal Analisis Rasio Solvabilitas Terhadap Laporan Keuangan untuk Menilai Tingkat Kinerja Keuangan Perusahaan 